\title{
Efek Hepatotoksik Jus Pinang Muda (Areca catechu) pada Tikus
}

\section{Hepatotoxicity Effect of Raw Betel Nut Juice (Areca catechu) in Rats}

\author{
Ave O Rahman \\ Laboratorium Farmakologi Fakultas Kedokteran dan IImu Kesehatan Universitas Jambi
}

\begin{abstract}
ABSTRAK
Hepatoksik akibat obat dan herbal merupakan penyebab kerusakan hepar yang menyebabkan morbiditas dan mortalitas. Jus pinang muda (Areca catechu) merupakan minuman herbal yang dikonsumsi oleh sebagian masyarakat di Jambi sebagai penambah stamina dengan takaran 5 biji pinang setara dengan 20gr/70kgBB atau 250mg/kgBB. Berdasarkan beberapa studi, pinang dosis $1000 \mathrm{mg} / \mathrm{kgBB}$ dapat menurunkan kadar glukosa darah, sedangkan median lethal dose (LD 50) adalah $>15.000 \mathrm{mg} / \mathrm{kgBB}$. Efek konsumsi jus pinang jangka panjang terhadap organ hepar belum diketahui. Penelitian ini merupakan uji pendahuluan untuk melihat efek pemberian jus pinang selama 45 hari terhadap organ hepar. Hewan coba adalah Rattus norvegicus galur Sprague Dawley, jantan, 2-3 bulan, berat 150-200 gram yang setelah diaklimatisasi dan dibagi secara random ke dalam 4 kelompok yaitu Kelompok I diberikan aquadest, kelompok II, III dan IV diberikan masing-masing jus pinang dosis $250 \mathrm{mg} / \mathrm{kgBB}, 1.000 \mathrm{mg} / \mathrm{kgBB}$, dan $10.000 \mathrm{mg} / \mathrm{kgBB}$. Perlakuan diberikan sekali sehari selama 45 hari. Dilakukan pemeriksaan histopatologi menggunakan pewarnaan Hematoxillin Eosin. Hasil pemeriksaan histopatologi menunjukkan gambaran kerusakan tipe hepatoseluler yaitu perdarahan, dilatasi sinusoid, inflamasi portal, inflamasi lobular, lobular dissarray, nekrosis, interface hepatitis dan mikrosteatosis pada kelompok jus pinang dengan derajat kerusakan hepar pada dosis $10.000 \mathrm{mg} / \mathrm{kgBB}$ lebih berat. Konsumsi jus pinang dosis 250-10.000mg/kgBB selama 45 hari dapat menimbulkan kerusakan hepar pada tikus.
\end{abstract}

Kata Kunci: Biji pinang, hepar, hepatotoksik, histopatologi, Jambi

\begin{abstract}
Hepatoxic due to drugs and herbs is the cause of liver damage that causes morbidity and mortality. Juice of raw betel nut (Areca catechu) is an herbal beverage that is consumed by some people in Jambi as a stamina booster with a dose of 5 betel nuts equivalent to $20 \mathrm{gr} / 70 \mathrm{kgBW}$ or $250 \mathrm{mg} / \mathrm{kgBW}$. Based on several studies, betel nut dosage of $1000 \mathrm{mg} / \mathrm{kgBW} \mathrm{can} \mathrm{reduce}$ blood glucose level, while the median lethal dose (LD50) is $>15.000 \mathrm{mg} / \mathrm{kgBW}$. The effect of consuming long-term betel juice on liver is unknown. This research was a preliminary test to see the effect of betel juice administration for 45 days to the liver. Experimental animals were Sprague Dawley strain Rattus norvegicus, male, 2-3 months, $150-200$ gram of weight which had been acclimatized and randomly divided into 4 groups, i.e. Group I was given aquadest once daily for 45 days, group II, III and IV were given raw betel nut juice dose of $250 \mathrm{mg} / \mathrm{kgBW}, 1.000 \mathrm{mg} / \mathrm{kgBW}$ and $10.000 \mathrm{mg} / \mathrm{kgBW}$, respectively. Treatment was given once a day for 45 days. Histopathological examination was done using Hematoxillin Eosin staining. The results of histopathological examination showed a description of hepatocellular type damages, namely bleeding, sinusoid dilatation, portal inflammation, lobular inflammation, lobular disarray, necrosis, hepatitis interface, and microsteatosis in betel juice group with heavier liver damage at dose of $10.000 \mathrm{mg} / \mathrm{kgBW}$. Consumption of betel juice at a dose of 250-10.000mg/kgBW for 45 days can cause liver damage in mice.
\end{abstract}

Keywords: Betel nut, histopathology, hepatotoxicity, Jambi, liver

Korespondensi: Ave Olivia R. Laboratorium Farmakologi Fakultas Kedokteran dan IImu Kesehatan Universitas Jambi, Jl. Letjen Soeprapto no. 33 Telanaipura, Kota Jambi (samping RSUD Raden Mattaher Jambi) Tel. (0741)60246 Email: aveoliviarahman@unja.ac.id 


\section{PENDAHULUAN}

Hepatotoksik akibat obat merupakan salah satu penyebab penyakit hepar yang dapat menyebabkan morbiditas dan mortalitas yang serius $(1,2)$. Beberapa herbal diketahui dapat menyebabkan hepatotoksik baik pada penggunaan jangka panjang ataupun dosis besar (2-5). Hepatotoksik akibat konsumsi minuman atau obat herbal kurang mendapatkan perhatian karena anggapan bahwa bahan alam aman untuk dikonsumsi (2). Hepatotoksik merupakan kerusakan hepar dengan gambaran yang bervariasi tergantung jenis obat atau senyawa penyebabnya. Gambaran kerusakan hepar meliputi hepatoseluler, kolestatis dan campuran hepatoselulerkolestatis $(1,6)$.

Biji pinang muda (Areca catechu) dikonsumsi oleh sebagian masyarakat Jambi sebagai minuman untuk menambah stamina. Dosis jus pinang yang biasa dikonsumsi untuk penambah stamina adalah sekitar $250 \mathrm{mg} / \mathrm{kgBB}$. Biji pinang muda juga mempunyai efek menurunkan kadar glukosa darah $(7,8)$. Jus pinang muda dosis $1.000 \mathrm{mg} / \mathrm{kgBB}$ dapat menurunkan kadar glukosa darah sebesar 30,48\% (8). Median lethal dose (LD50) pinang muda adalah $>15.000 \mathrm{mg} / \mathrm{kgBB}$ (9).

Biji pinang mengandung karbohidrat, lemak, serat, asam amino, mineral dan polifenol seperti flavonoid, tanin, dan alkaloid. Alkaloid utama yang terkandung di biji pinang adalah arecoline (10). Arecoline merupakan salah satu alkaloid biji pinang yang dianggap sebagai agen hipoglikemia $(7,11)$. Selain itu, Arecoline dapat menginduksi sitotoksik dan kerusakan DNA pada sel hepar (12). Uji pada sel tikus C3H10T/12 menunjukkan ekstrak biji pinang bersifat karsinogenesis (13). Biji pinang dapat mempengaruhi hampir semua organ termasuk hepar (14). Hepar merupakan salah satu organ yang rentan terjadi kerusakan akibat konsumsi obat ataupun senyawa herbal dalam jangka panjang (15-17). Penelitian ini dilakukan untuk melihat efek konsumsi jus pinang muda terhadap hepar dalam jangka waktu 45 hari melalui penelitian eksperimental pada tikus.

\section{METODE}

Penelitian ini adalah penelitian eksperimental yang dilakukan pada Bulan Agustus-Oktober 2017 di Laboratorium Biomedik Fakultas Kedokteran dan IImu Kesehatan Universitas Jambi dan telah mendapatkan persetujuan etik dari Komisi Etik Fakultas Kedokteran dan Ilmu Kesehatan Universitas Jambi.

\section{Bahan}

Biji pinang muda diperoleh dari salah satu penjual jus pinang di Kota Jambi. Biji pinang yang digunakan adalah yang berasal dari buah pinang berwarna hijau. Setelah buah pinang dibelah, biji pinang diambil. Biji pinang dihaluskan dan ditambahkan dengan aquadest sehingga mempunyai kadar $250 \mathrm{mg} / \mathrm{mL}, 1.000 \mathrm{mg} / \mathrm{mL}$ dan $10.000 \mathrm{mg} / \mathrm{mL}$.

Hewan percobaan yang digunakan adalah tikus jantan galur Sprague Dawley berusia sekitar 2-3 bulan, memiliki berat 150-200 gram yang diperoleh dari Fakultas Kedokteran dan Ilmu Kesehatan Universitas Jambi. Jumlah sampel adalah 5 ekor tikus setiap kelompok.

Prosedur Kerja

Perlakuan
Setelah aklimatisasi, tikus dibagi secara random menjadi 4 kelompok yaitu Kelompok I diberikan aquadest, kelompok II diberikan jus pinang dosis $250 \mathrm{mg} / \mathrm{KgBB}$, Kelompok III diberikan jus pinang dosis $1.000 \mathrm{mg} / \mathrm{kgBB}$ dan kelompok IV diberikan jus pinang dosis $10.000 \mathrm{mg} / \mathrm{kgBB}$. Jus pinang dibuat setiap hari yang diberikan satu kali sehari selama 45 hari dengan menggunakan sonde.

\section{Pemeriksaan Enzim Hepar Alanine Aminotranferase (ALT)}

Pengambilan darah melalui sinus retrobulbi untuk pemeriksaan enzim hepar ALT dilakukan sebelum perlakuan dan setelah 45 hari perlakuan.

\section{Pembedahan dan Penilaian}

Pembedahan dilakukan pada hari ke-46 dan dilakukan pengambilan organ hepar untuk pemeriksaan histopatologi dengan pengecatan HE (Hematoxilin Eosin). Penilaian organ hepar dilakukan oleh satu ahli Patologi Anatomi secara blind meliputi: perdarahan, dilatasi sinusoid, lobular dissaray, inflamasi lobular, nekrosis, interface hepatitis, mikrosteatosis, kolestasis, akumulasi lipofusin, dan fibrosis yang dibaca pada seluruh lapangan pandang. Penilaian secara semi kualitatif dengan skor: $0=$ tidak ditemukan (normal), 1=ditemukan derajat ringan $\leq 30 \%$, 2=ditemukan derajat sedang 31-50\%, 3=ditemukan derajat berat $>50 \%$. Rerata skor histopatologi pada setiap sampel dihitung dengan cara menjumlahkan keseluruhan skor lesi (18).

\section{Analisis data}

Data dalam penelitian ini mempunyai distribusi tidak normal sehingga data dianalisis dengan uji Kruskal Wallis yang dilanjutkan dengan uji Mann Whitney $U$ untuk mengetahui beda rerata lebih dari 2 kelompok. Uji Wilcoxon digunakan untuk menganalisis beda rerata kadar ALT sebelum dan sesudah perlakuan. Hasil uji statistik dinyatakan signifikan jika nilai $p<0,05$.

\section{HASIL}

\section{Gambaran Histopatologi Hepar}

Gambaran histopatologi jaringan hepar pada kelompok jus pinang ditemukan tanda inflamasi portal, inflamasi lobular, lobular dissarray, nekrosis, interface hepatitis, perdarahan, dilatasi sinusoid dan mikrosetatosis. Sedangkan tanda kerusakan kolestasis, akumulasi lipofusin dan fibrosis tidak ditemukan. Pada kelompok jus pinang dosis $10.000 \mathrm{mg} / \mathrm{kgBB}$ ditemukan $100 \%$ sampel mengalami inflamasi portal, inflamasi lobular, lobular dissarray, nekrosis, interface hepatitis, perdarahan, dilatasi sinusoid, sedangkan mikrosteatosis hanya terjadi pada $80 \%$ sampel. Kelompok jus pinang $250 \mathrm{mg} / \mathrm{kgBB}$ dan $1.000 \mathrm{mg} / \mathrm{kgBB}$ juga mengalami kerusakan hepar dengan persentase lebih rendah dibandingkan dengan dosis $10.000 \mathrm{mg} / \mathrm{kgBB}$ (Tabel $1)$.

Tabel 1. Gambaran histopatologi jaringan hepar pada tiap kelompok

\begin{tabular}{llrrrr}
\hline & & \multicolumn{3}{c}{ Persentase sampel tiap kelompok } \\
\cline { 3 - 6 } & & KI & \multicolumn{1}{c}{ KII } & \multicolumn{1}{c}{ KIII } & \multicolumn{1}{c}{ KIV } \\
\hline \multirow{2}{*}{ Inflamasi Portal } & Normal & $80 \%$ & $20 \%$ & 0 & 0 \\
& Ringan & $20 \%$ & $40 \%$ & 0 & $40 \%$ \\
& Sedang & 0 & $40 \%$ & $100 \%$ & $60 \%$ \\
& Berat & 0 & 0 & 0 & 0 \\
\hline
\end{tabular}


Tabel 1. Gambaran histopatologi jaringan hepar pada tiap kelompok (Lanjutan)

\begin{tabular}{|c|c|c|c|c|c|}
\hline & & \multicolumn{4}{|c|}{ Persentase sampel tiap kelompok } \\
\hline & & KI & KII & KIII & KIV \\
\hline Inflamasi & Normal & $100 \%$ & $60 \%$ & $20 \%$ & 0 \\
\hline \multirow[t]{3}{*}{ Lobular } & Ringan & 0 & $20 \%$ & $20 \%$ & $40 \%$ \\
\hline & Sedang & 0 & $20 \%$ & $60 \%$ & $60 \%$ \\
\hline & Berat & 0 & 0 & 0 & 0 \\
\hline Lobular & Normal & $100 \%$ & $60 \%$ & $60 \%$ & 0 \\
\hline \multirow[t]{3}{*}{ dissarray } & Ringan & 0 & $40 \%$ & $40 \%$ & $100 \%$ \\
\hline & Sedang & 0 & 0 & 0 & 0 \\
\hline & Berat & 0 & 0 & 0 & 0 \\
\hline \multirow[t]{4}{*}{ Nekrosis } & Normal & $100 \%$ & $60 \%$ & $60 \%$ & 0 \\
\hline & Ringan & 0 & $40 \%$ & $40 \%$ & $100 \%$ \\
\hline & Sedang & 0 & 0 & 0 & 0 \\
\hline & Berat & 0 & 0 & 0 & 0 \\
\hline Interface & Normal & $100 \%$ & $60 \%$ & $60 \%$ & 0 \\
\hline \multirow[t]{3}{*}{ Hepatitis } & Ringan & 0 & $40 \%$ & $40 \%$ & $100 \%$ \\
\hline & Sedang & 0 & 0 & 0 & 0 \\
\hline & Berat & 0 & 0 & 0 & 0 \\
\hline \multirow[t]{4}{*}{ Perdarahan } & Normal & $80 \%$ & 0 & 0 & 0 \\
\hline & Ringan & $20 \%$ & $40 \%$ & $20 \%$ & 0 \\
\hline & Sedang & 0 & $40 \%$ & $40 \%$ & $20 \%$ \\
\hline & Berat & 0 & $20 \%$ & $40 \%$ & $80 \%$ \\
\hline Dilatasi & Normal & $100 \%$ & $20 \%$ & 0 & 0 \\
\hline \multirow[t]{3}{*}{ sinusoid } & Ringan & 0 & 0 & 0 & 0 \\
\hline & Sedang & 0 & $40 \%$ & $20 \%$ & 0 \\
\hline & Berat & 0 & $40 \%$ & $80 \%$ & $100 \%$ \\
\hline Akumulasi & Normal & $100 \%$ & $100 \%$ & $100 \%$ & $100 \%$ \\
\hline \multirow[t]{3}{*}{ lipofusin } & Ringan & 0 & 0 & 0 & 0 \\
\hline & Sedang & 0 & 0 & 0 & 0 \\
\hline & Berat & 0 & 0 & 0 & 0 \\
\hline \multirow[t]{4}{*}{ Kolestasis } & Normal & $100 \%$ & $100 \%$ & $100 \%$ & $100 \%$ \\
\hline & Ringan & 0 & 0 & 0 & 0 \\
\hline & Sedang & 0 & 0 & 0 & 0 \\
\hline & Berat & 0 & 0 & 0 & 0 \\
\hline \multirow[t]{4}{*}{ Mikrosteatosis } & Normal & $100 \%$ & $60 \%$ & $60 \%$ & $20 \%$ \\
\hline & Ringan & 0 & $40 \%$ & $40 \%$ & $40 \%$ \\
\hline & Sedang & 0 & 0 & 0 & $40 \%$ \\
\hline & Berat & 0 & 0 & 0 & 0 \\
\hline \multirow[t]{4}{*}{ Fibrosis } & Normal & $100 \%$ & $100 \%$ & $100 \%$ & $100 \%$ \\
\hline & Ringan & 0 & 0 & 0 & 0 \\
\hline & Sedang & 0 & 0 & 0 & 0 \\
\hline & Berat & 0 & 0 & 0 & 0 \\
\hline
\end{tabular}

Perhitungan skor histopatologi dilakukan untuk melihat hubungan besarnya dosis jus pinang dengan derajat kerusakan (Tabel 2). Berdasarkan hasil uji Kruskall Wallis, didapatkan paling tidak terdapat perbedaan skor histopatologi untuk lesi inflamasi portal, inflamasi lobular, lobular dissarray, nekrosis, interface hepatitis, perdarahan dan dilatasi sinusoid antara 2 kelompok. Untuk lesi mikrosteatosis tidak ada perbedaan bermakna antar kelompok.

Tabel 2. Rerata skor histopatologi tiap lesi pada masingmasing kelompok

\begin{tabular}{lrrrrr}
\hline & \multicolumn{4}{c}{ Rerata skor histopatologi \pm SD } & Nilai \\
\cline { 2 - 5 } & \multicolumn{1}{c}{ KI } & \multicolumn{1}{c}{ KII } & \multicolumn{1}{c}{ KIII } & KIV & p $^{*}$ \\
\hline Inflamasi portal & $0,2 \pm 0,44$ & $1,2 \pm 0,83$ & 2,0 & $1,6 \pm 0,54$ & 0,007 \\
Inflamasi lobular & 0 & $0,6 \pm 0,89$ & $1,4 \pm 0,89$ & $1,6 \pm 0,54$ & 0,018 \\
Lobular dissarray & 0 & $0,4 \pm 0,54$ & $0,4 \pm 0,54$ & 1,0 & 0,020 \\
Nekrosis & 0 & $0,4 \pm 0,54$ & $0,4 \pm 0,54$ & 1,0 & 0,020 \\
Interface hepatitis & 0 & $0,4 \pm 0,54$ & $0,4 \pm 0,54$ & 1,0 & 0,020 \\
Perdarahan & $0,2 \pm 0,44$ & $1,8 \pm 0,83$ & $2,2 \pm 0,83$ & $2,8 \pm 0,44$ & 0,005 \\
Dilatasi sinusoid & 0 & $2,0 \pm 1,22$ & $2,8 \pm 0,44$ & 3,0 & 0,003 \\
\hline
\end{tabular}

Tabel 2. Rerata skor histopatologi tiap lesi pada masingmasing kelompok (Lanjutan)

\begin{tabular}{lrrrrrr}
\hline & \multicolumn{4}{c}{ Rerata skor histopatologi \pm SD } & Nilai \\
\cline { 2 - 6 } & KI & KII & KIII & KIV & p $^{*}$ \\
\hline Akumulasi lipofusin & 0 & 0 & 0 & 0 & 1,000 \\
Kolestasis & 0 & 0 & 0 & 0 & 1,000 \\
Mikrosteatosis & 0 & $0,4 \pm 0,54$ & $0,4 \pm 0,54$ & $1,2 \pm 0,83$ & 0,060 \\
Fibrosis & 0 & 0 & 0 & 0 & 1,000 \\
\hline
\end{tabular}

Keterangan: *Uji Kruskal Wallis

Uji Kruskal Wallis dilanjutkan dengan Uji Mann Whitney U untuk mengetahui kelompok mana yang mempunyai perbedaan. Hasil uji Mann Whitney U (Tabel 3) menunjukkan ada perbedaan bermakna $(p<0,05)$ skor histopatologi untuk lesi inflamasi portal, inflamasi lobular, lobular dissarray, nekrosis, interface hepatitis, perdarahan dan dilatasi sinusoid antara kelompok kontrol dengan kelompok jus pinang $10.000 \mathrm{mg} / \mathrm{kgBB}$. Antar kelompok jus pinang dosis $250 \mathrm{mg} / \mathrm{kgBB}, 1.000 \mathrm{mg} / \mathrm{kgBB}$ dan $10.000 \mathrm{mg} / \mathrm{kgBB}$ tidak ada perbedaan yang bermakna.

Tabel 3. Hasil uji Mann Whitney U antar kelompok setiap lesi

\begin{tabular}{lcccccc}
\hline & \multicolumn{6}{c}{ Nilai p } \\
\cline { 2 - 7 } & $\begin{array}{c}\text { KI dan } \\
\text { KII }\end{array}$ & $\begin{array}{c}\text { KI dan } \\
\text { KIII }\end{array}$ & $\begin{array}{c}\text { KI dan } \\
\text { KIV }\end{array}$ & $\begin{array}{c}\text { KII dan KII dan } \\
\text { KIII }\end{array}$ & $\begin{array}{c}\text { KIV } \\
\text { KIV dan }\end{array}$ \\
\hline KIV \\
\hline Inflamasi portal & 0,054 & 0,004 & 0,011 & 0,053 & 0,419 & 0,134 \\
Inflamasi lobular & 0,136 & 0,017 & 0,005 & 0,180 & 0,077 & 0,811 \\
Lobular disarray & 0,134 & 0,134 & 0,003 & 1,000 & 0,050 & 0,050 \\
Nekrosis & 0,134 & 0,134 & 0,003 & 1,000 & 0,050 & 0,050 \\
Interface hepatitis & 0,134 & 0,134 & 0,003 & 1,000 & 0,050 & 0,050 \\
Perdarahan & 0,012 & 0,009 & 0,005 & 0,439 & 0,054 & 0,189 \\
Dilatasi sinusoid & 0,003 & 0,004 & 0,003 & 0,189 & 0,053 & 0,317 \\
Mikrosteatosis & 0,134 & 0,134 & 0,018 & 1,000 & 0,118 & 0,118 \\
\hline
\end{tabular}

Tabel 4 menunjukkan rerata total skor histopatologi setiap sampel pada masing-masing kelompok. Total skor histopatologi tertinggi adalah kelompok jus pinang dosis $10.000 \mathrm{mg} / \mathrm{kgBB}$ diikuti kelompok jus pinang dosis $1.000 \mathrm{mg} / \mathrm{kgBB}$ dan $250 \mathrm{mg} / \mathrm{kgBB}$ secara berurutan. Semakin tinggi skor menunjukkan semakin berat derajat kerusakan. Hasil uji Kruskal Wallis menunjukkan ada perbedaan rerata total skor histopatologi yang bermakna paling tidak antar 2 kelompok. Uji Kruskal Wallis dilanjutkan dengan uji Mann Whitney $U$. Berdasarkan hasil uji Mann Whitney $U$, rerata total skor histopatologi kelompok kontrol lebih rendah dibandingkan kelompok jus pinang dan perbedaan tersebut bermakna $(p<0,05)$. Rerata total skor histopatologi antar kelompok jus pinang dosis 250 $\mathrm{mg} / \mathrm{kgBB}, 1.000 \mathrm{mg} / \mathrm{kgBB}$ dan $10.000 \mathrm{mg} / \mathrm{kgBB}$ tidak berbeda bermakna $(p>0,05)$. Hal ini menunjukkan bahwa jus pinang menyebabkan kerusakan hepar akan tetapi derajat kerusakan tidak bersifat dose dependent.

Tabel 4. Rerata total skor histopatologis setiap sampel pada kelompok

\begin{tabular}{lrc}
\hline Kelompok & Rerata \pm SD & Nilai P* \\
\hline KI & $0,4 \pm 0,54^{\text {a }}$ & 0,002 \\
KII & $7,2 \pm 3,56^{\text {b }}$ & \\
\hline
\end{tabular}


Tabel 4. Rerata total skor histopatologis setiap sampel pada kelompok (Lanjutan)

\begin{tabular}{ccc}
\hline Kelompok & Rerata \pm SD & Nilai P* $^{*}$ \\
\hline KIII & $10,0 \pm 2,91^{\mathrm{b}}$ \\
KIV & $13,2 \pm 1,64^{\mathrm{c}}$ & \\
\hline
\end{tabular}

Keterangan: *Uji Kruskal Wallis, hasil uji Mann Whitney U, abc (notasi berbeda menunjukkan perbedaan signifikan)
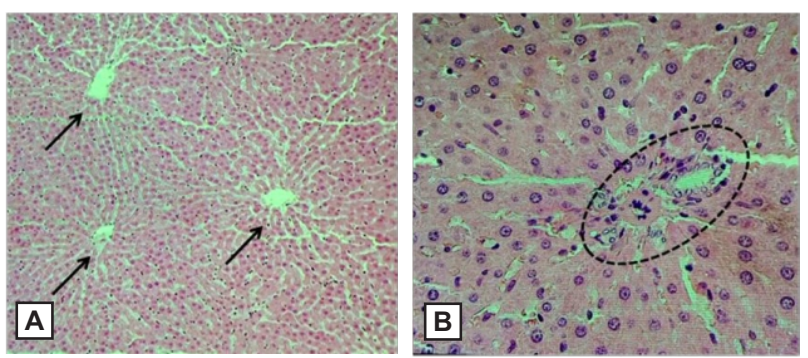

Gambar 1. Jaringan hepar normal pada kelompok kontrol

Keterangan: A. Hepar normal (pembesaran 100x), B. Hepar normal (pembesaran 400x). Tanda panah (A) adalah vena sentralis, lingkaran (B) adalah triad porta

Gambaran arsitektur lobulus hepar yang normal (Gambar 1A) terdiri dari vena sentralis dengan sel hepatosit yang mengelilinginya secara radier dengan susunan yang teratur. Sel hepatosit (Gambar B) tampak berbentuk poligonal dengan nukleus terletak di tengah.
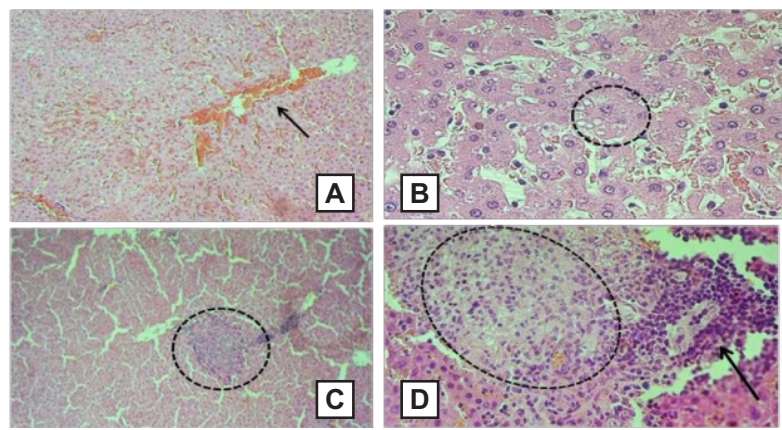

Gambar 2. Jaringan hepar pada kelompok jus pinang

Keterangan: C. perdarahan (tanda panah, pembesaran 100x) D. Mikrosteatosis (lingkaran, pembesaran 400x) E. Inflamasi lobular (lingkaran) dan lobular dissarray (pembesaran 100x). F. Interface hepatitis tampak granuloma (lingkaran) dan inflamasi portal (panah) (pembesaran 400x)

Gambaran histopatologi pada kelompok jus pinang (Gambar 2) menunjukkan adanya perdarahan (A), mikrosteatosis (B), lobular dissarray dan inflamasi lobular (C) dan interface hepatitis (D). Mikrosteatosis tampak seperti ada vakuola kosong dengan ukuran kecil dan multipel dalam sitoplasma hepatosit dan nukleus hepatosit tetap di tengah tidak tergeser oleh vakuola tersebut. Pada lobular dissarray, susunan arsitektur hepatosit tampak tidak beraturan. Inflamasi ditandai dengan infiltrasi sel radang yang dimulai dari sekitar porta (inflamasi porta) yang dapat meluas ke parenkim periportal menjadi interface hepatitis. Apabila inflamasi meluas ke satu lobulus hepar disebut inflamasi lobular.

\section{Kadar ALT}

Hasil pemeriksaan fungsi hepar melalui pengukuran kadar enzim ALT sesudah 45 hari perlakukan didapatkan hasil terjadi peningkatan dibandingkan sebelum perlakuan (Tabel 5). Peningkatan kadar ALT pada kelompok jus pinang dosis $1.000 \mathrm{mg} / \mathrm{kgBB}$ dan dosis $10.000 \mathrm{mg} / \mathrm{kgBB}$ tidak bermakna $(p>0,05)$, sedangkan pada kelompok kontrol dan jus pinang dosis $250 \mathrm{mg} / \mathrm{kgBB}$ terjadi peningkatan yang bermakna $(p<0,05)$. Peningkatan kadar ALT pada kelompok kontrol sebesar 1,02 kali lipat dan pada kelompok jus pinang dosis $250 \mathrm{mg} / \mathrm{kgBB}$ sebesar 0,6 kali lipat.

Tabel 5. Perbedaan rerata kadar enzim hepar ALT (u/L) pada kelompok jus pinang

\begin{tabular}{lrrr}
\hline \multirow{2}{*}{ Kelompok } & \multicolumn{2}{c}{ Kadar ALT (U/L) \pm SD } & \multirow{2}{*}{ Nilai p* } \\
\cline { 2 - 3 } & \multicolumn{1}{c}{ Sebelum } & \multicolumn{1}{c}{ Sesudah } & \\
\hline KI & $57,2 \pm 7,5$ & $115,8 \pm 16,1$ & 0,043 \\
KII & $51,2 \pm 8,9$ & $84,2 \pm 13,3$ & 0,017 \\
KIII & $52,4 \pm 7,9$ & $70,8 \pm 14,1$ & 0,068 \\
KIV & $62,8 \pm 11,9$ & $66 \pm 25,8$ & 0,786 \\
\hline Keterangan: *Uji Wilcoxon & &
\end{tabular}

\section{DISKUSI}

Pada penelitian ini, pemberian jus pinang memberikan gambaran inflamasi portal, interface hepatitis, inflamasi lobular, nekrosis hepatosit dan tidak ditemukan kolestatis. Hal ini menunjukkan adanya kerusakan hepar tipe hepatoseluler pada kelompok yang diberikan jus pinang (6). Kerusakan hepatoseluler diawali dari inflamasi disekitar porta yang dapat meluas ke parenkim periportal yang disebut interface hepatitis. Interface hepatitis menunjukkan kerusakan bersifat kronis dan dapat berlanjut menjadi fibrosis (19). Beberapa obat atau senyawa herbal dapat menyebabkan sinusoidal obstruction syndrome (SOS). Sindrom ini terjadi karena adanya kerusakan sel endothelial sinusoid. Monocrotaline merupakan senyawa alkaloid yang dapat menyebabkan edema dan kerusakan sel endotelial sinusoid sehingga sel darah merah ekstravasasi ke parenkim hepar menyebabkan perdarahan. Obstruksi sinusoid terjadi akibat embolisme dari agregasi sel sinusoid, sel darah merah dan monosit. Adanya obstruksi akan menyebabkan dilatasi sinusoid (20).

Penilaian derajat kerusakan hepar berhubungan dengan derajat nekrosis, fibrosis, mikrosteatosis dan reaksi duktular (1). Pada kelompok jus pinang dosis $10.000 \mathrm{mg} / \mathrm{kgBB}$, sebanyak $100 \%$ sampel mengalami inflamasi portal, inflamasi lobular, lobular dissarray, nekrosis, interface hepatitis, perdarahan dan dilatasi sinusoid. Disisi lain kejadian mikrosteatosis hanya ditemukan pada $80 \%$ sampel. Persentase kerusakan pada kelompok jus pinang dosis $250 \mathrm{mg} / \mathrm{kgBB}$ dan dosis $1.000 \mathrm{mg} / \mathrm{kgBB}$ didapatkan hasil yang lebih rendah. Hasil analisis derajat kerusakan jaringan hepar yang dihitung dari total skor histopatologi juga menunjukkan semakin besar dosis jus pinang semakin besar pula derajat kerusakannya, walaupun berdasarkan uji statistik perbedaan tersebut tidak bermakna.

Arecoline merupakan senyawa alkaloid utama yang 
terkandung dalam biji pinang (10). Biji pinang mengandung arecoline sekitar $7,5 \mathrm{mg} /$ gram biji pinang (21). Arecoline merupakan senyawa yang dapat menyebabkan hepatotoksik terutama pada dosis tinggi dan jangka lama $(22,23)$. Studi Zhou et al., menunjukkan bahwa pemberian arecoline hydrobromide dosis $5 \mathrm{mg} / \mathrm{kgBB}$ yang diberikan 2 kali sehari selama 28 hari menyebabkan kerusakan hepatosit yang ditandai dengan gambaran inflamasi dan steatosis (22). Salah satu penyebab mikrosteatosis adalah kerusakan mitokondria sel hepatosit (24). Semua kelompok jus pinang pada penelitian ini juga terjadi inflamasi dan mikrosteatosis dengan derajat lebih berat pada dosis $10.000 \mathrm{mg} / \mathrm{kgBB}$ akan tetapi tidak signifikan perbedaannya dibandingkan dosis $250 \mathrm{mg} / \mathrm{kgBB}$ dan $1.000 \mathrm{mg} / \mathrm{kgBB}$.

Kadar ALT dan Alkaline phospatase (ALP) dapat digunakan untuk menentukan tipe kerusakan hepar. Kerusakan hepatoselular biasanya ditandai dengan peningkatan kadar ALT >2 kali normal atau rasio ALT/ALP $\geq 5$ (6). Sebuah studi menunjukkan bahwa ekstrak air biji pinang dapat menyebabkan kerusakan hepar yang ditandai dengan peningkatan enzim hepar pada dosis $800-1200 \mathrm{mg} / \mathrm{kgBB}$ selama 28 hari (25). Pada penelitian

\section{DAFTAR PUSTAKA}

1. Kleiner DE, Chalasani NP, Lee WM, et al. Hepatic Histological Findings in Suspected Drug-Induced Liver Injury: Systematic Evaluation and Clinical Associations. Hepatology. 2014; 59(2): 661-670.

2. Licata A, Macaluso FS, and Craxi A. Herbal Hepatotoxicity: A Hidden Epidemic. Internal and Emergency Medicine. 2013; 8(1): 13-22.

3. Krishna YR, Mittal V, Grewal P, Fiel MI, and Schiano T. Acute Liver Failure Caused by "Fat Burners" and Dietary Supplements: A Case Report and Literature Review. Canadian Journal of Gastroenterology. 2011; 25(3): 157-160.

4. Teschke R, Genthner A, and Wolff A. Kava Hepatotoxicity: Comparison of Aqueous, Ethanolic, Acetonic Kava Extracts and Kava-Herbs Mixtures. Journal of Ethnopharmacology. 2009; 123(3): 378384.

5. Li X, Qu C, He Q, et al. Acute Hepatitis Induced by A Chinese Herbal Product Qibao Meiran Wan: A Case Study. International Journal of Clinical and Experimental Medicine. 2015; 8(7): 11624-11627.

6. Ramachandran R and Kakar S. Histological Patterns in Drug-Induced Liver Disease. Journal of Clinical Pathology. 2009; 62(6): 481-492.

7. Amudhan MS and Begum H. Alpha-Glucosidase Inhibitory and Hypoglycemic Activities of Areca catechu Extract. Pharmacognosy Magazine. 2008; 4(15): 223-227.

8. Rahman $\mathrm{AO}$ and Utami RF. Hypoglycemic Effect of Raw Betel Nut. Proceeding Pertemuan Ilmiah Tahunan Ikatan Ahli Farmakologi Indonesia ke 16. Jakarta, Oktober 20-22, 2016: hal. 13-15.

9. Sari LM, Suyatna FD, Utami S, et al. Acute Oral Toxicity Study of Areca catechu Linn. Aqueous Extract in Sprague Dawley Rats. Asian Journal of ini juga didapatkan peningkatan kadar ALT yang signifikan secara statistik setelah 45 hari pemberian jus pinang dosis $250 \mathrm{mg} / \mathrm{kgBB}$. Akan tetapi, peningkatan kadar ALT tersebut belum masuk kriteria hepatotoksik, karena hanya meningkat 0,6 kali.

Diagnosis hepatotoksik akibat obat ditegakkan apabila terjadi peningkatan kadar enzim hepar 1-3 kali lipat dan semua penyebab kerusakan hepar lainnya telah disingkirkan $(1,26)$. Kadar enzim hepar tidak selalu berkorelasi dengan derajat kerusakan jaringan hepar. Kerusakan hepar biasanya akan terjadi peningkatan kadar enzim hepar antara lain ALT, tetapi tidak selalu menunjukkan adanya kerusakan yang signifikan secara klinis karena hepar mempunyai kemampuan regenerasi sel yang cukup tinggi (1).

Hasil penelitian ini menunjukkan konsumsi jus pinang dosis $250 \mathrm{mg} / \mathrm{kgBB}$ yang biasa dikonsumsi masyarakat Jambi dapat menimbulkan kerusakan pada organ hepar tikus jika dikonsumsi selama 45 hari. Uji lanjutan berupa uji toksisitas subkronis perlu dilakukan untuk memberikan data keamanan konsumsi jus pinang dalam jangka panjang.

Pharmaceutical and Clinical Research. 2014; 7(5): 2022.

10. Jaiswal P, Kumar P, Singh VK, and Singh DK. Areca catechu L.: A Valuable Herbal Medicine Againts Different Health Problems. Research Journal of Medicinal Plant. 2011; 5(2): 145-152.

11. Prabhakar PK and Doble M. Interaction of Phytochemicals with Hypoglycemic Drugs on Glucose Uptake in L6 Myotubes. Phytomedicine. 2011; 18(4): 285-291.

12. Chou WW, Guh JY, Tsai JF, et al. Arecoline-Induced Growth Arrest and P21WAF1 Expression are Dependent on P53 in Rat Hepatocytes. Toxicology. 2008; 243(1-2): 1-10.

13. Yeh $\mathrm{CY}$, Chen $\mathrm{HM}$, Chang MC, et al. Cytotoxicity and Transformation of C3H10T1/2 Cells Induced by Areca Nut Components. Journal of the Formosan Medical Association. 2016; 115(2): 108-112.

14. Garg A, Chaturvedi P, and Gupta PC. A Review of the Systemic Adverse Effects of Areca Nut or Betel Nut. Indian Journal of Medical and Paediatric Oncology. 2014; 35(1): 3-9.

15. Frenzel C and Teschke R. Herbal Hepatotoxicity: Clinical Characteristics and Listing Compilation. International Journal of Molecular Sciences. 2016; 17(5): 1-38.

16. Stournaras E and Tziomalos K. Herbal MedicineRelated Hepatotoxicity. World Journal of Hepatology. 2015; 7(19): 2189-2193.

17. Calitz C, du Plessis L, Gouws C, et al. Herbal Hepatotoxicity: Current Status, Examples, and Challenges. Expert Opinion on Drug Metabolism \& Toxicology. 2015; 11(10): 1551-1565.

18. Arsad SS, Esa NM, and Hamzah H. Histopathologic Changes in Liver and Kidney Tissues from Male Sprague Dawney Rats Treated with Rhaphidophora 
Decursiva (Roxb.) Schott Extract. Journal of Cytology Histology. 2014; 2014: 1-6.

19. Theise ND and Saxena N. Algorithmic Approach to Diagnosis of Liver Disorders. In: Odze RD and Goldblum JR (Eds). Surgical Pathology of the GI Tract, Liver, Billiary Tract, and Pancreas. 3rd edition. Philadelphia: Elsevier Saunders; 2015; pp. 11431169.

20. Fan CQ and Crawford JM. Sinusoidal Obstruction Syndrome (Hepatic Veno-Occlusive Disease). Journal of Clinical and Experimental Hepatology. 2014; 4(4): 332-346.

21. Amudhan S, Begum VH, and Hebbar KB. A Review on Phytochemical and Pharmacological Potential of Arecha Catechu L. Seed. International Journal of Pharmaceutical Sciences and Research. 2012; 3(11): 4151-4157.

22. Zhou J, Sun Q, Yang Z, and Zhang J. The Hepatotoxicity and Testicular Toxicity Induced by
Arecoline in Mice and Protective Effects of Vitamins $C$ and $E$. The Korean Journal of Physiology \& Pharmacology. 2014; 18(2): 143-148.

23. Wei X, Zhang J, Niu J, Zhou X, Li J, and Li B. Evaluation of Arecoline Hydrobromide Toxicity After A 14-Day Repeated Oral Administration in Wistar Rats. PLoS ONE. 2015; 10(4): 1-23.

24. Nassir F, Rector S, Hammoud GM, and Ibdah JA. Pathogenesis and Prevention of Hepatic Steatosis. Gastroenterology \& Hepatology. 2015; 11(3): 167-175.

25. Adediji JA, Adediji TA, and Eze GI. Effects of Short Term Oral Administration of Aqueous Extracts of Areca Nut (Areca catechu) on Liver Profile of Adult Wistar Rats. IOSR Journal of Dental and Medical Sciences. 2015; 14(10): 62-67.

26. Kullak-Ublick GA, Andrade RJ, Merz M, End P, et al. Drug-Induced Liver Injury: Recent Advances in Diagnosis and Risk Assessment. Gut. 2017; 66(6): 1154-1164 